\title{
Application of GIS technology in the protection of monuments on the example of Historic Monuments
}

\author{
Krzysztof Rząsa ${ }^{1, *}$, Marek Ogryzek $^{1}$, and Mateusz Ciski $^{1}$ \\ ${ }^{1}$ Faculty of Geodesy, Geospatial and Civil Engineering, Institute of Geography and Land Management, University of Warmia and \\ Mazury in Olsztyn, Prawochenskiego Street 15, 10-720 Olsztyn, Poland
}

\begin{abstract}
According to the criteria set by The National Heritage Board of Poland, an non-movable monument of trans-regional importance, of high historical, scientific and artistic values; relevant to the Polish cultural heritage, consolidated in the social consciousness by being a source of inspiration for future generations, may be recognized as Historic Monument. As at April 20, 2018, there are 91 Historic Monuments in Poland. The objects were characterized by: location, type, age, date of recognition as a Historic Monument. Several GIS tools, such as: Kernel Density, diagram map with proportional symbols, and various forms of graduated symbols were used to analyse and visualise the spatial data. Results were presented in tabular form and on a series of created maps. The applied GIS tools allowed to elaborate and show spatial, temporal and generic differentiation of analysed objects; which allowed to draw conclusions in this area, included at the end of the article.
\end{abstract}

\section{Introduction}

Recognition of an object or area as a Historic Monument (pol. pomnik historii), in accordance with art. 7 of the act of 23 July 2003 on the protection of monument and the care of monuments [1], along with an entry in the register of objects of cultural heritage (pol. rejestr zabytków), an entry on the List of Heritage Treasures (pol. Lista Skarbów Dziedzictwa), Cultural Park (pol. park kulturowy) establishment and protection regulations in spatial planning documents, is one of the legal forms of protection of monuments in Poland. This form was created as a kind of ennoblement of the most valuable monuments in Poland [2], although according to $\mathrm{B}$. Kwiatkowska-Kopka [3], from the formal point of view, there is no doubt that recognition as a Historic Monument is not accompanied by any support and its managers must, in fact, only rely on their own strength alone. Owners of buildings that have been ennobled and included in the list of Historic Monument do not acquire any public or legal rights. The more active owners are trying to obtain financial resources, supporting their efforts with the brand of Historic Monument. However, this does not change the fact that Historic Monuments should be supported by appropriate legal, financial and organizational solutions. According to Zalasińska [4], recognition as a Historic Monument does not entail any additional legal consequences. It does not change the legal status of the object from the point of view of the forms of the protection of monuments. Therefore, it does not give the conservation administration additional instruments of operation, and protected objects and areas are in fact subject to a preservation regime, resulting from an entry in the register of objects of cultural heritage or obtaining the status of a cultural park. The only effect is in fact an impact on social awareness. Konopka [5] indicates, that thanks to recognition as a Historic Monuments, this form has obtained a formal and permanent place in Polish law for the protection of cultural property, and Minister of Culture and National Heritage was obliged to determine the manner of carrying out the protection of Historic Monuments, which in consequence meant the right legal formula for the protection of areas. In accordance to art. 15 of the Act [1], the President of the Republic of Poland, at the request of the Minister of Culture and National Heritage, by regulation may acknowledge as Historic Monument a non-movable monument entered in the register of objects of cultural heritage, or a Cultural Park of special value for culture. Minister of Culture and National Heritage may submit the application after obtaining the opinion of the Council for the Protection of Monuments. The withdrawal of recognition of the nonmovable monument as a Historic Monument takes place in the procedure provided in its recognition. Minister of Culture and National Heritage can present to The World Heritage Committee an application for entry of a Historic Monument on "World Heritage List", to protect this object on the basis of Convention Concerning the Protection of the World Cultural and Natural Heritage, adopted by UNESCO during the 17th session in Paris on November 16, 1972.

An object recognized as a Historic Monument becomes an element of cultural heritage and is subject to the principles of protection characteristic of this type of objects. Such activities can be observed all over the world [6-8].

\footnotetext{
* Corresponding author: krzysztof.rzasa@uwm.edu.pl
} 
Of the currently existing 91 Historic Monuments in Poland, as much as $40 \%$ are objects related to religion. Culture and cultural values are commonly associated in conservation with the spiritual and religious significance of landscapes and wildlife, manifested in sacred sites or spiritual landscapes, and in rituals, customs and ceremonies [9-13].

In this article, the Authors presented the possibilities of using GIS software in analyses related to Historic Monuments in Poland as a form of the protection of monuments. The GIS contains tools for conducting analysis and spatial modelling, and allow the user to both generate new information based on existing data, and to search information in multiple layers of data. GIS also allows the visualisation and analysis of the data crossreferenced by time (which shows time trends), and for the data to be used for the purposes of protection of monuments.

\section{Materials and methods}

To conduct analyses using GIS software, in the first step, a detailed analysis of legal grounds of functioning of Historic Monuments in Poland and detailed inventory and classification was made. According to the criteria set by National Centre for Research and Documentation of Monuments (currently The National Heritage Board of Poland, pol. Narodowy Instytut Dziedzictwa), an nonmovable monument of trans-regional importance, of high historical, scientific and artistic values; relevant to the Polish cultural heritage, consolidated in the social consciousness by being a source of inspiration for future generations, may be covered by this form of additional protection. It is advisable for these monuments to: maintain the original spatial composition or have undergone slight transformations, be uniformly stylish or have clear and harmonized layers, be properly exposed in urban space or landscape, retained their original relationship with the environment, be the works of outstanding artists, e.g. architects, planners, landscape architects, gardeners; be well preserved or in a condition allowing their revalorization, and be the subject of conservation care. From a formal point of view, a regulation of the President of the Republic of Poland is required (the procedure indicated in the Introduction). Such criteria as of 20/04/2018 meets 91 objects. These are various objects that, in order to improve further analysis, were divided into 9 generic-functional groups: sacral and sepulchral units (36 objects), urban systems (16), residential units (11), monuments of technology (10), works of architecture and construction (6), cultural landscapes (4), archaeological monuments (3), defensive structures (2) and battlefields (3). For all objects: the dates of creation, location in a given voivodeship, detailed location and date of recognition as a Historic Monument were collected. On such a prepared database, analysis using GIS applications were carried out. The planned analyses required precise point data, presenting the location Historic Monuments in Poland. Therefore, the available online GIS services were analysed, in terms of the ability to automatically download the necessary data.
The only service that met this requirement was the service DanePubliczne.gov.pl. This service is designed to collect in one place data of special importance for the development of innovation in the country and the development of the information society. Data downloaded in CSV format (with columns containing geographical coordinates) was converted to point data using the "Make XY Event Layer" tool, from the ArcMap component of the ArcGIS software. The acquired data set has been updated and supplemented with 10 objects, recognized as Historic Monuments on 20/04/2018.

If we assume that the location of Historic Monuments is associated with territorial division units [14] (in the case of a this analysis - voivodeships), presentation of data in the form of a cartogram (Fig. 1) will show the basic way of data distribution. According to the classification of the map, a darker grey shade means more Historic Monuments in a given voivodeship.

To present the year of recognition of the object as a Historic Monuments, graduated symbols (Fig. 2) was used - data has been divided into four time intervals, depending on the date of recognition (up to 1994, 19952007, 2008-2012, 2013-2018), which were marked with gradually darker points (which means more recent Historic Monuments). However, more recent Historic Monuments do not necessarily mean later created objects - Fig. 3 in a similar way as Fig. 2 (with additional geometric signatures) shows the age of objects recognized as a Historic Monuments.

In order to visualize 9 generic-functional groups into which Historic Monuments were divided, a diagram map (cartodiagram) was created (Fig. 4). Circular diagrams with the numbers of Historic Monuments from individual generic-functional groups were drawn on the borders of all voivodeships. In addition, the size of the diagram shows the total number of Historic Monuments in a given voivodeship.

Using the Kernel Density function (Fig. 5), the density of the variable distribution was determined based on known locations of Historic Monuments in Poland 15]. Due to the domination of religious objects indicated in the Introduction, to study the spatial distribution of the types of Historic Monuments, data on generic-functional groups from four main groups was selected (sacral and sepulchral units -36 objects, urban systems -16 , residential units 11 , monuments of technology -10 ), and then the Kernel Density function was used again to create four another maps (Fig. 6. Sacral and sepulchral units, Fig. 7. Urban systems, Fig. 8. Residential units and Fig. 9. Monuments of technology).

\section{Results and discussion}

Recognition the first map presents distribution of Historic Monuments in Polish voivodeships (Fig. 1). Cartogram (with added points with exact location of monuments) presents south-western Poland as rich in Historic Monuments. On average, one voivodeship has 6 historical monuments, while only the Greater Poland and Lower Silesian voivodeships have more than 9 (10 and 12 respectively). 
Analysis of the year of recognition of the object as a Historical Monument is shown in Fig. 2. The largest and darkest symbols mean objects that are later recognized as a Historic Monument (monuments recognized in the years 2013-2018 constitute approx. 40\%).

In order to compare the age of the object to the year it is recognised as a Historic Monument, in a similar manner as in Fig. 2, Fig. 3 shows the four ranges of centuries of the objects' creation (from BCE, I-XII century, XIIIXVIII, and XIX-present).

The cartodiagram (Fig. 4) depicting the division of Historic Monuments into generic-functional groups shows very well the domination of religious objects in almost all of Poland.

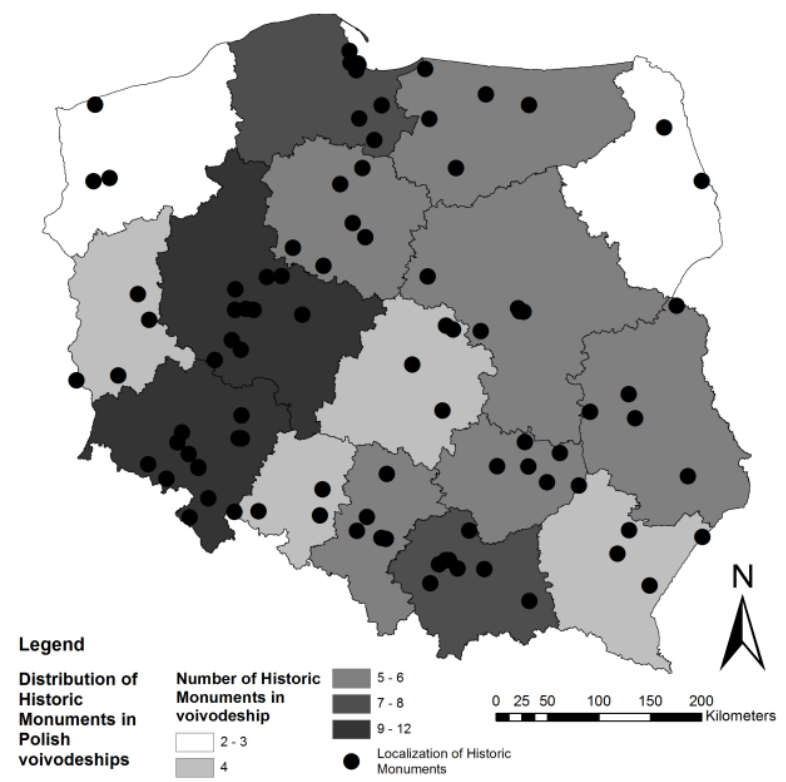

Fig. 1. Distribution of Historic Monuments in polish voivodeships.

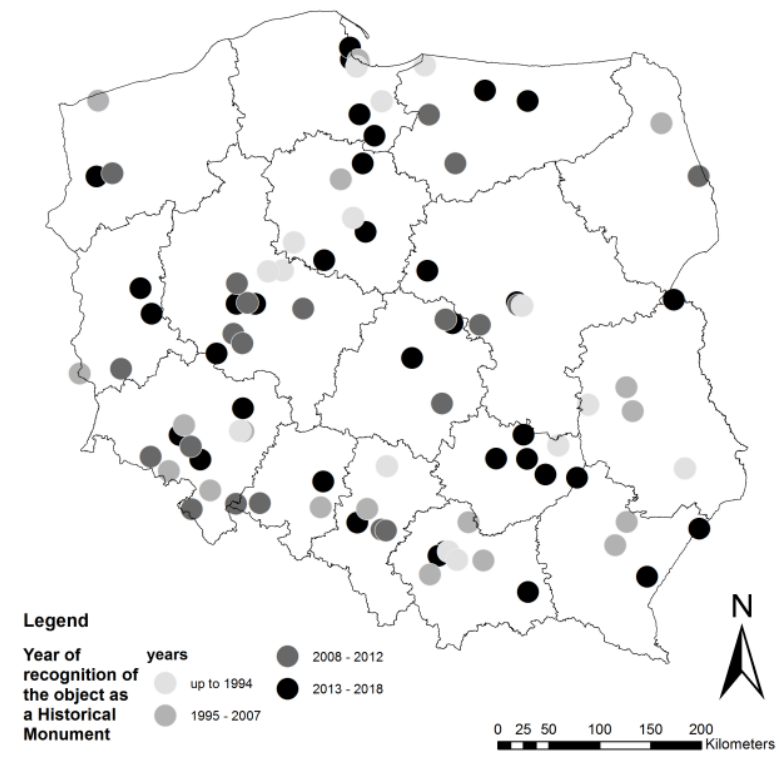

Fig. 2. Year of recognition of the object as a Historical Monument.

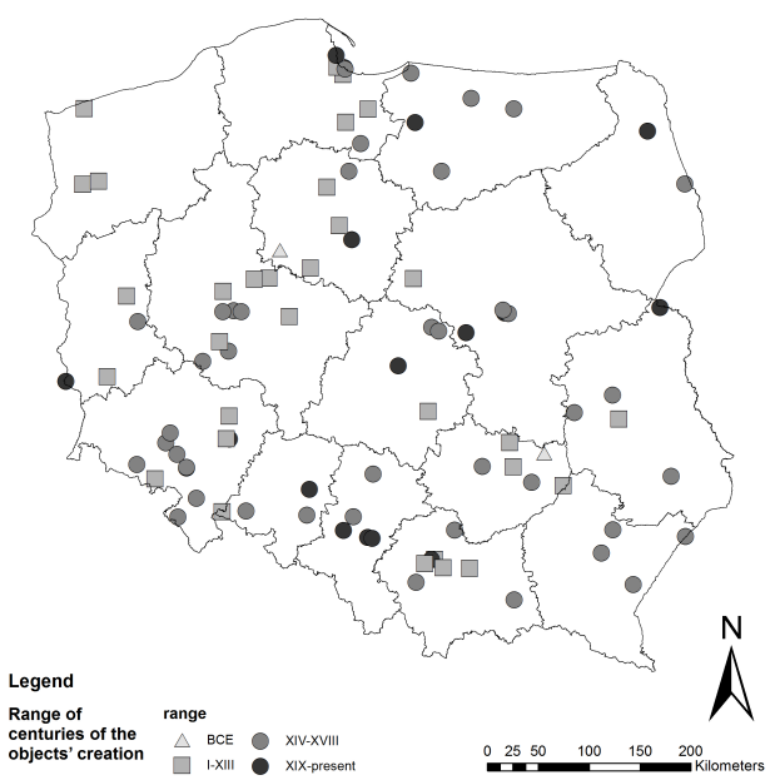

Fig. 3. Range of centuries of the objects' creation.

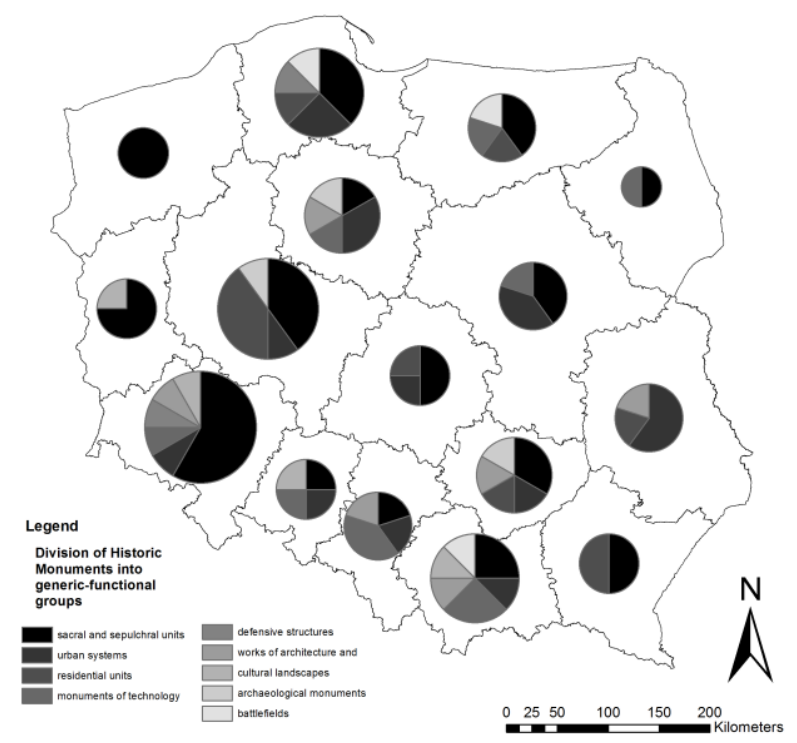

Fig. 4. Division of Historic Monuments into generic-functional groups.

Analysis of the Kernel Density function (Fig. 5) more accurately than the cartogram illustrates the density of the location of Historic Monuments in Poland. By removing the limitations in the form of administrative boundaries, the natural, spatial distribution of historical monuments was examined $[14,15]$. Fig 5 presents several clusters of historical monuments: the vicinity of the Tri-City, Poznan and Wrocław.

In order to examine the influence of various genericfunctional groups on the density of the location of Historic Monuments, following maps show the density of the distribution of groups: Fig. 6. Sacral and sepulchral units, Fig. 7. Urban systems, Fig. 8. Residential units and Fig. 9. Monuments of technology. 


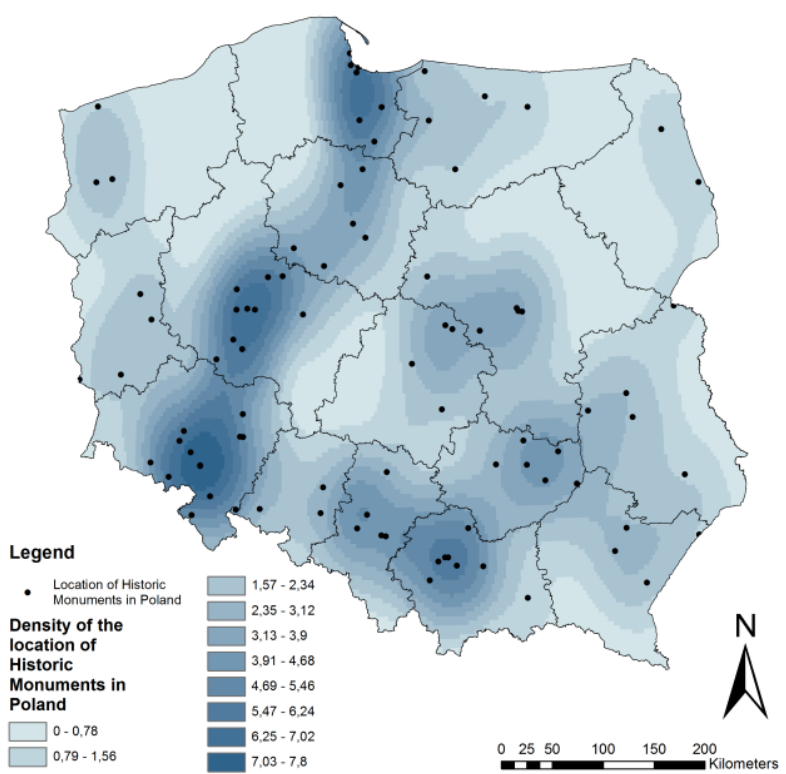

Fig. 5. Density of the location of Historic Monuments in Poland.

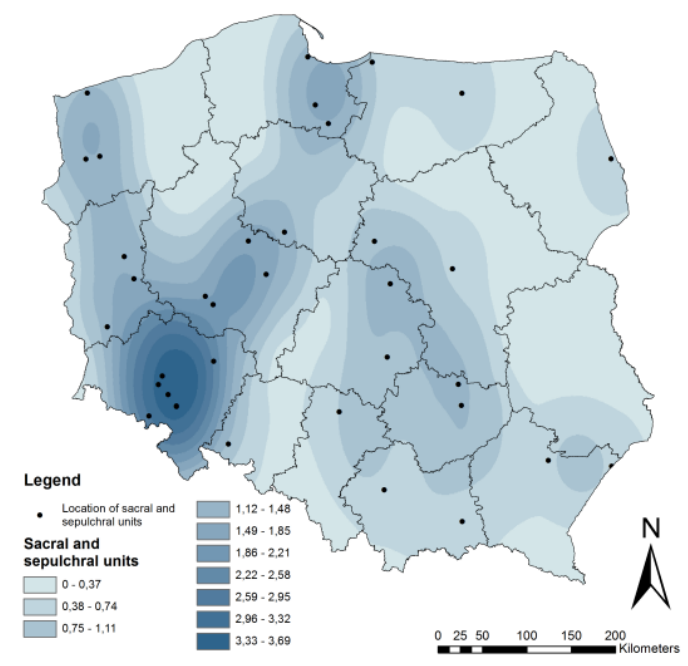

Fig. 6. Sacral and sepulchral units.

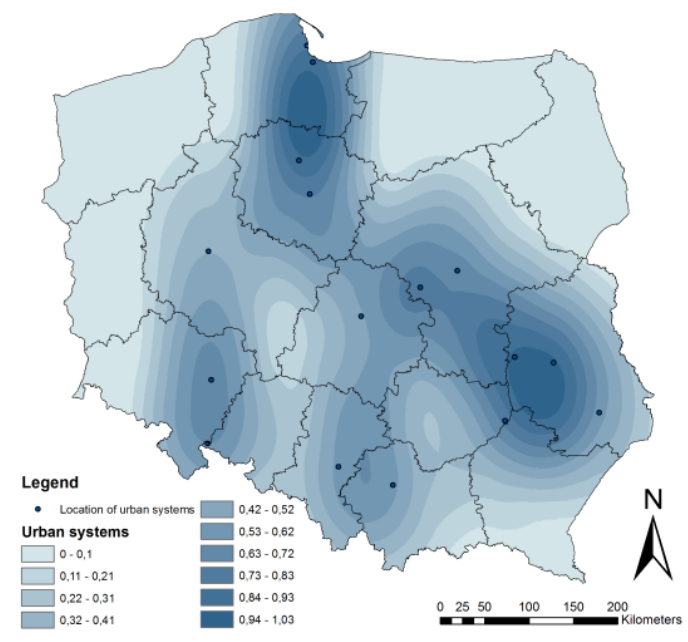

Fig. 7. Urban systems.

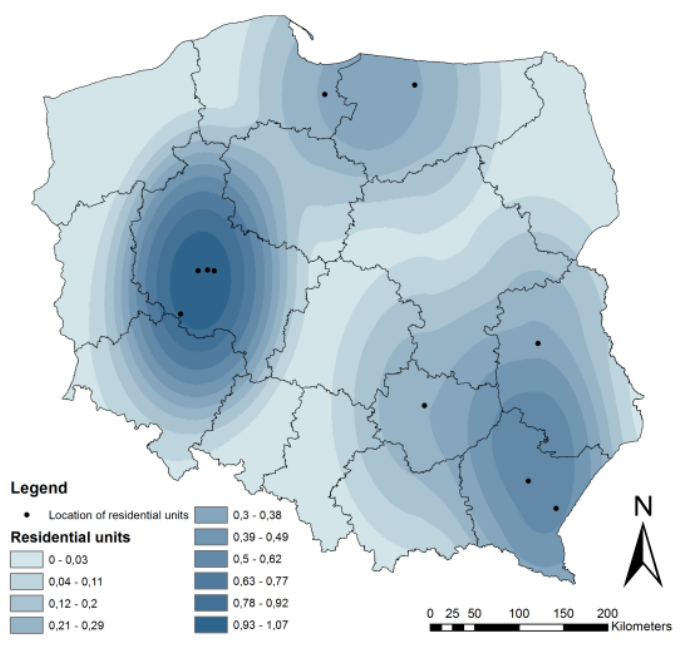

Fig. 8. Residential units.

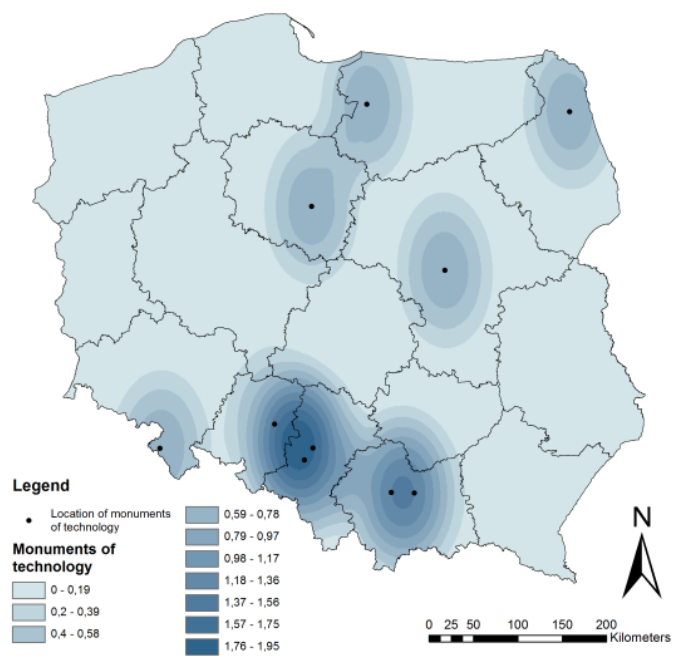

Fig. 9. Monuments of technology.

\section{Conclusions}

Analyses carried out allowed to formulate the following conclusions:

- GIS technologies gives a wide range of spatial analysis capabilities. Presented methods of spatial analysis are a very good tool in the analysis of monuments - Websites and online databases are an excellent spatial data resource. Necessary data on Historic Monuments (resulting from the applied methodology) are available for free download, automatically.

- Occurrence of Historic Monuments does not seem to correlate with specific voivodeships - a few large clusters can be noticed, but there is no continuity and parallel distribution. The locations corresponds with historically Polish areas (with the exception of the Lower Silesian voivodeship, but in this case more than half of the Historic Monuments are sacral and sepulchral objects).

- The conclusion from point 3 is additionally visible after applying the division into the age range - the oldest objects (BCE and I-XIII) they dominate in the southwestern part of the country, while newer ones (interval 
XIV-XVIII definitely, XIX-present range - less) cover the entire surface of the country without any visible trends.

- Partitions of Poland and the history of the country is indirectly visible on the maps - there is an accumulation of Historic Monuments on historically Polish lands (Greater Poland, Pomeranian, Mazovia, Subcarpathia), but also on the Recovered Territories (Lower Silesia)

- Representing 40\% of all Historic Monuments, sacral and sepulchral objects on Fig. 6 fit well into the overall density shown in Fig. 5. Residential units (Fig. 8) are responsible for aggregation around the city of Poznań. Monuments of technology (Fig. 9) occur almost only in the south of the country, and urban systems (Fig. 8) seem to be responsible for the rest of the country (map is almost the exact opposite of sacral and sepulchral units).

- Urban systems (Fig. 8) are closely related primarily to the historical cities of Poland.

\section{References}

1. The Act on the Protection of Monuments and the Care of Historical Monuments. Parliament. Journal of Laws from 2014, No 1446 as amended (2003)

2. H. Kisilowska, Prawne aspekty ochrony nieruchomości zabytkowych, Mazowsze, Studia Regionalne, Mazowieckie Biuro Planowania Regionalnego w Warszawie, No 7, pp. 59-65 (2011) (in Polish) DOI: $10.21858 / \mathrm{msr}$

3. B. Kwiatkowska-Kopka, Pomnik historii - $i$ inne formy nobilitacji zabytku jako priorytety na rzecz powszechnego dostepu do dziedzictwa $i$ jego promocji, Wiadomości Konserwatorskie 2015 No 44, pp. $98-109 \quad$ (2015) (in Polish) DOI:10.17425/WK44MONUMENT

4. K. Zalasińska, Pole bitwy pod Grunwaldem pomnikiem historii, Spotkania z zabytkami, 3-4 marzec-kwiecień 2011, pp. 47-48 (2011) (in Polish)

5. G. Mikusiński , H.P. Possingham \& M. Blicharska, Biodiversity priority areas and religions - a global analysis of spatial overlap. Oryx, The International Journal of Conservation, published for Fauna \& Flora International. No 48, pp. 17-22 (2014)

6. P. M. Protopsaltis. Book Review: Cultural Heritage in International Investment Law and Arbitration, by Valentina Vadi. (Cambridge: Cambridge University Press. 2014). 35 Journal of International Arbitration, Kluwer Law International BV, The Netherlands. Issue 2, pp. 267-271 (2018)

7. E. Lagrange, S. Oeter, R. Uerpmann-Wittzack, eds. Cultural Heritage and International Law: Objects, Means and Ends of International Protection. Springer International Publishing, Basel. (2018) DOI:10.1007/978-3-319-78789-3

8. X. Jiao, J. Wang. Context Protection and Inheritance in the Process of Urbanization. 2nd International Conference on Education, Management and Applied Social Science (EMASS), pp. 170-174 (2018) DOI:10.12783/dtssehs/emass2018/20409
9. K. Metcalfe , R. Ffrench-Constant \& I. Gordon. Sacred sites as hotspots for biodiversity: the Three Sisters Cave complex in coastal Kenya. Oryx, The International Journal of Conservation, published for Fauna \& Flora International. No 44, pp. 118-123 (2010)

10. N. Gupta, A. Kanagavel, P. Dandekar, N. Dahanukar, K. Sivakumar, V.B. Mathur \& R. Raghavan. God's fishes: religion, culture and freshwater fish conservation in India. Oryx, The International Journal of Conservation, published for Fauna \& Flora International. No 50, pp. 244-249 (2016)

11. E.P. Riley. The importance of human-macaque folklore for conservation in Lore Lindu National Park, Sulawesi, Indonesia. Oryx, The International Journal of Conservation, published for Fauna \& Flora International. No 44, pp. 235-240 (2010)

12. J.E. McKay, F.M. Mangunjaya, Y. Dinata , S.R. Harrop \& F. Khalid, Practise what you preach: a faith-based approach to conservation in Indonesia. Oryx, The International Journal of Conservation, published for Fauna \& Flora International. No 48, pp. 23-29 (2014)

13. G. Mikusiński , H.P. Possingham \& M. Blicharska. Biodiversity priority areas and religions - a global analysis of spatial overlap. Oryx, The International Journal of Conservation, published for Fauna \& Flora International. No 48, pp. 17-22 (2014)

14. B. Medyńska-Gulij, Kartografia i geowizualizacja. Warszawa: Wydawnictwo Naukowe PWN (2011) (in Polish)

15. P. A. Longley, M. F. Goodchild, D. J. Maguire, and D. W. Rhind, Geographic Information Systems and Science, 2nd Revise. John Wiley \& Sons Ltd., New York (2005) 